\title{
Growth Patterns Crassostrea sp in Various Cultural Media of Marine Water Area, Banda Aceh
}

\author{
Fauzi Arja ${ }^{1}$, Muhammad A. Sarong ${ }^{1}$, Suhendrayatna Suhendrayatna ${ }^{2}$, and Ismul Huda ${ }^{1 *}$ \\ ${ }^{1}$ Biology Education Departement, Universitas Syiah Kuala, Banda Aceh, Indonesia \\ ${ }^{2}$ Chemical Engineering Departement, Universitas Syiah Kuala, Banda Aceh, Indonesia
}

\begin{abstract}
Oysters belong to the bivalve class, which has a soft body and is protected by two hard shells. Living in groups and sticking together on various substrates. Oysters have high nutritional content so that the need for oysters continues to increase unbalanced with the availability of oysters in the habitat. The study aimed to see the pattern of growth of various culture media of oysters. The research was carried out from May until June 2019. Samples were taken in three water areas based on cultivation media with a purposive sampling technique when the water receded, and data analysis was carried out in the Laboratory. Oysters from cultivation media showed the growth pattern ( $b=0.47$ to 0.65 ) with a coefficient of determination ( $R 2=0.25$ to 0.83 ) while oysters without cultivation media showed growth pattern ( $b=0.44$ to 0.51 ) with the coefficient of determination $(\mathrm{R} 2=0.19$ to 0.27$)$ and all show allometric negative growth patterns $(b<3)$. The results of the value of $b$ and the coefficient of determination obtained in the culture media are greater than the values obtained without the cultivation media, which shows that the use of cultivation media is very effective in oyster production.
\end{abstract}

Keywords: Crassostrea sp, growth patterns, cultivation media, oyster.

\section{Introduction}

Oysters as one of the high quality aquatic food ingredients so that the need for oysters for the community continues to increase which is not in accordance with the availability of oysters in the habitat [1]. This causes the harvesting process in large capacity and does not follow a decent harvest size so that the availability of oysters in the waters area continues to be threatened. The cause of the dramatic decline in the population of oysters has been caused by over-harvesting, combined with habitat loss, pollution, and disease [2]. Excessive catching of oysters is identified as the main cause of the decline in the population of oysters [17]. Then carried out the development of various cultivation media that can help the production of oysters and increase the income of local oyster farmers. Development of cultivation media in accordance with methods and complete equipment in accordance with the needs of oyster habitat [10].

The waters of the Banda Aceh City were developed by three methods of oyster culture, namely the floating culture method using a floating basket as an enlargement process, Hang rope method uses multilevel plastic plates weighted with ballast and a stake culture method that uses used tires and bamboo for sticking the oyster spat media in the waters. Each oyster is found in the waters of the city of Banda Aceh, allegedly there are varied growth patterns. This study aims to determine the pattern of oyster growth in the waters of Banda Aceh City. The existence of information about this oyster growth pattern becomes important information for those who need it. An important aspect of this research is to assess the effectiveness of the production of oysters produced.

\section{Materials and Methods}

\subsection{Study Area}

The study was conducted in the waters area of Banda Aceh City (Figure 1), namely Tibang. The village located at the coordinate point N 05035'35.2"- E 095020'40.2", Alue Naga Village is at the coordinates N 05 $35^{\prime} 55.1^{\prime \prime}$ E $095^{\circ} 21^{\prime} 18.3^{\prime \prime}$ and Alue Deah Teungoh is at the coordinate point N 05033'59.2"- E 095018'10.3". Determination of the place of this study using a purposive sampling technique

This study uses the ex post facto method, by looking at the effect on the observed variables and reporting according to conditions that occur in the field [9]. Data collection was carried out starting in May and June 2019 according to the area of observation. Oyster length and weight are two basic components in biology at the individual and population level [13]. Measurement of water and substrate water quality is done by measuring temperature, salinity and $\mathrm{pH}$ recorded according to the research station 


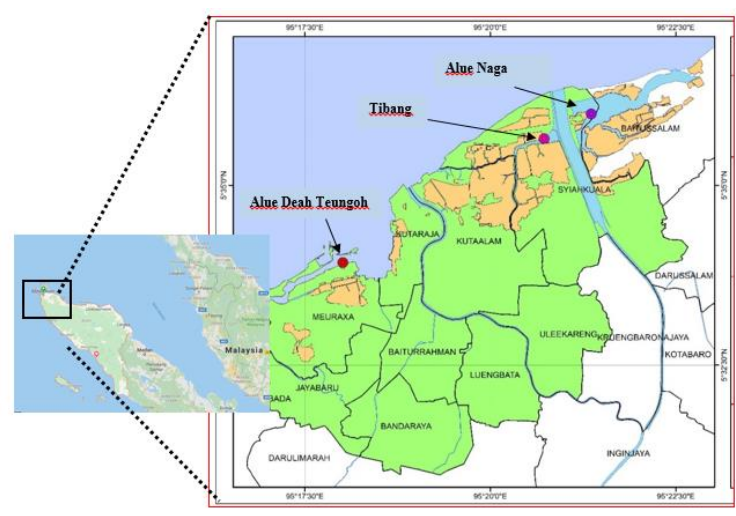

Figure 1. Map of Research Location

\subsection{Data analysis}

Data analysis is done through equation relations [6] as follows :

Information:

$$
\mathcal{W}=a L^{b}
$$

$\mathrm{W}=$ total weight $(\mathrm{g})$

$\mathrm{L}=$ total length $(\mathrm{mm})$

$\mathrm{a}$ and $\mathrm{b}=$ constants
The value of $b$ found, then compared with the value of $b$ from several results of research on other shells. To get parameters $\mathrm{a}$ and $\mathrm{b}$, regression analysis is used with $\log \mathrm{W}$ as ' $y$ ' and $\log L$ as ' $x$ ', the regression equation is obtained :

$$
y=a+b x
$$

To test the value of $b=3$ or $b \neq 3$ the following categories can be seen:

1. $b=3$, Isometric, means that the growth in length is proportional to the growth in weight.

2. $\mathrm{b} \neq 3$, Allometric :

a. Allometric is positive if $b>3$ means weight gain is faster than length gain and,

Allometric is negative if $b<3$ means that the length increase is faster than the weight gain.

\section{Results and Discussion}

The observations on three waters areas were conducted from May to June 2019. The growth patterns varied between cultivation media and natural habitats.
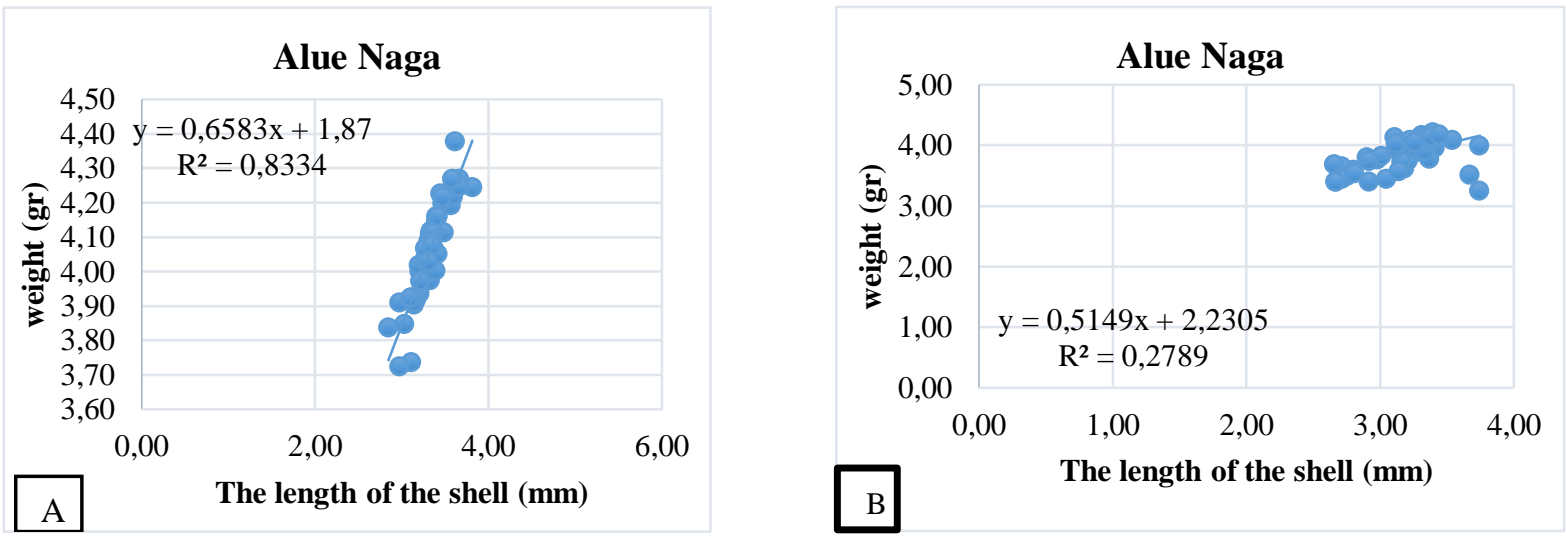

Figure 2. Patterns of oyster growth in the Alue Naga watershed. Cultivation media (A) found b value of 0.6583 with a coefficient of determination (R2) of 0.8334 and Natural Habitat (B) value of b obtained by 0.5149 with a coefficient of determination (R2) of 0.2789 .
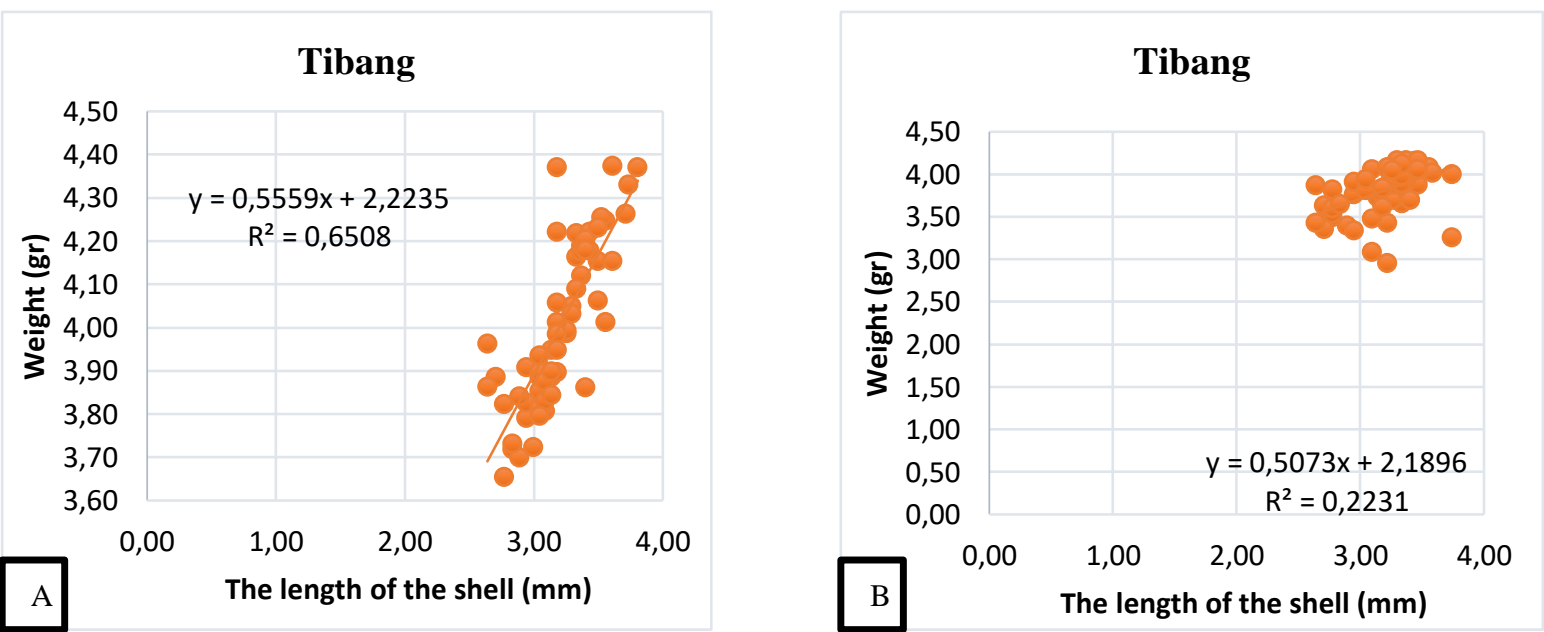

Figure 3. The growth pattern of the oyster waters of the Tibang aquaculture media (A) was found to be $a b$ value of 0.5559 with the coefficient of determination being at 0.6508 and Natural Habitat (B) found to be the Tibang the value of b obtained was 0.5073 with a coefficient of determination (R2) is at 0.2231 . 

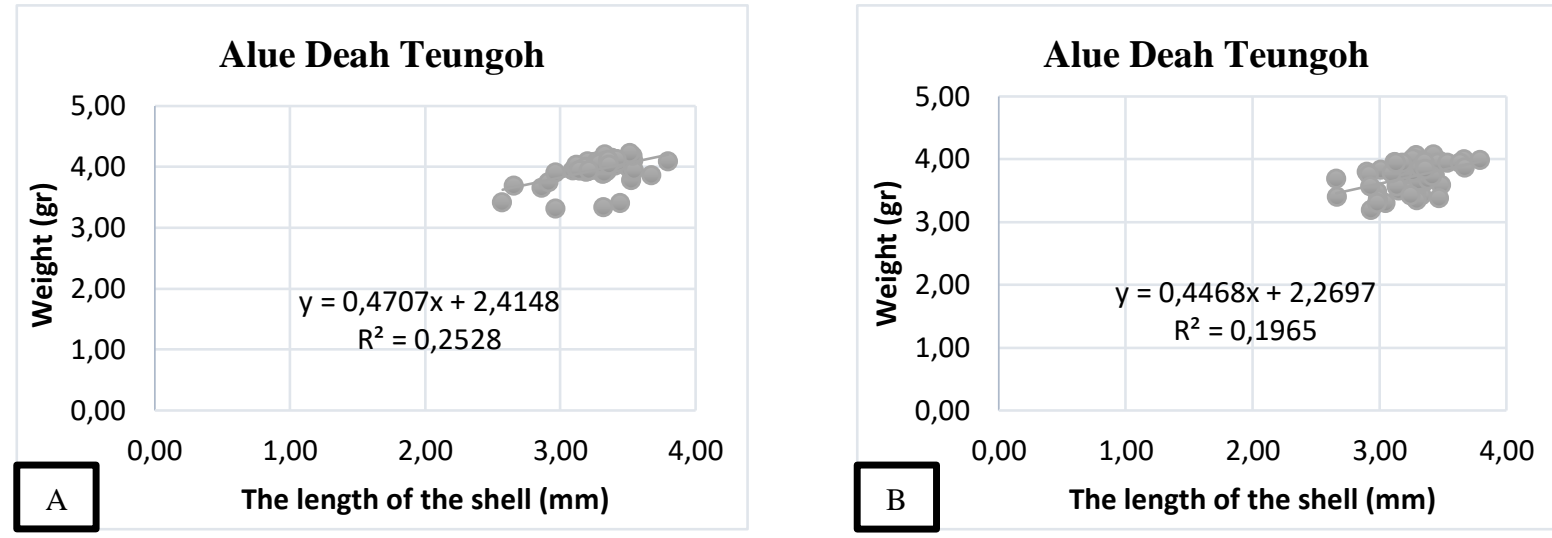

Figure 4. The growth pattern of oyster waters in Alue Deah Teungoh aquaculture media (A) found the value of b is 0.4707 with a coefficient of determination (R2) 0.2528 and Natural Habitat (B) found the value of b obtained is 0.4468 with a coefficient of determination (R2) 0.1965 .

The growth pattern of Crassostrea sp in the Banda Aceh City waters area is Allometric negative with a value of $b<3$. Negative allometric growth indicates that length increase is more dominant when compared to weight gain [5]. Allometric growth patterns are negatively caused by competition, overfishing, and potential [16]. Weight and length of shells increase gradually according to habitat quality and food availability. Weight and length variations in aquatic biota as a guide to obesity, health, productivity, and physiological conditions [11].

This result is also seen from the value of determination efficiency $\left(\mathrm{R}^{2}\right)$ produced in the culture medium is higher than the value of $\mathrm{R}^{2}$ produced in natural habitats. The magnitude of the coefficient of determination $\left(\mathrm{R}^{2}\right)$ between 0 to 1 . If the coefficient of determination approaches one, the independent variable influences the dependent variable. the coefficient of determination $\left(\mathrm{R}^{2}\right)$ is displayed as a percentage [7]. This shows that oyster cultivation media is very effective in increasing the growth and growth of the oyster population. Changes in water quality will force bivalves to make new adaptations that affect the growth of oysters [3]. Water quality in a good range for growth of oysters is temperature 27.3 $30.1{ }^{\circ} \mathrm{C}, \mathrm{pH} 7.2-7.8$ and salinity $15-30 \mathrm{ppt}$ [19].
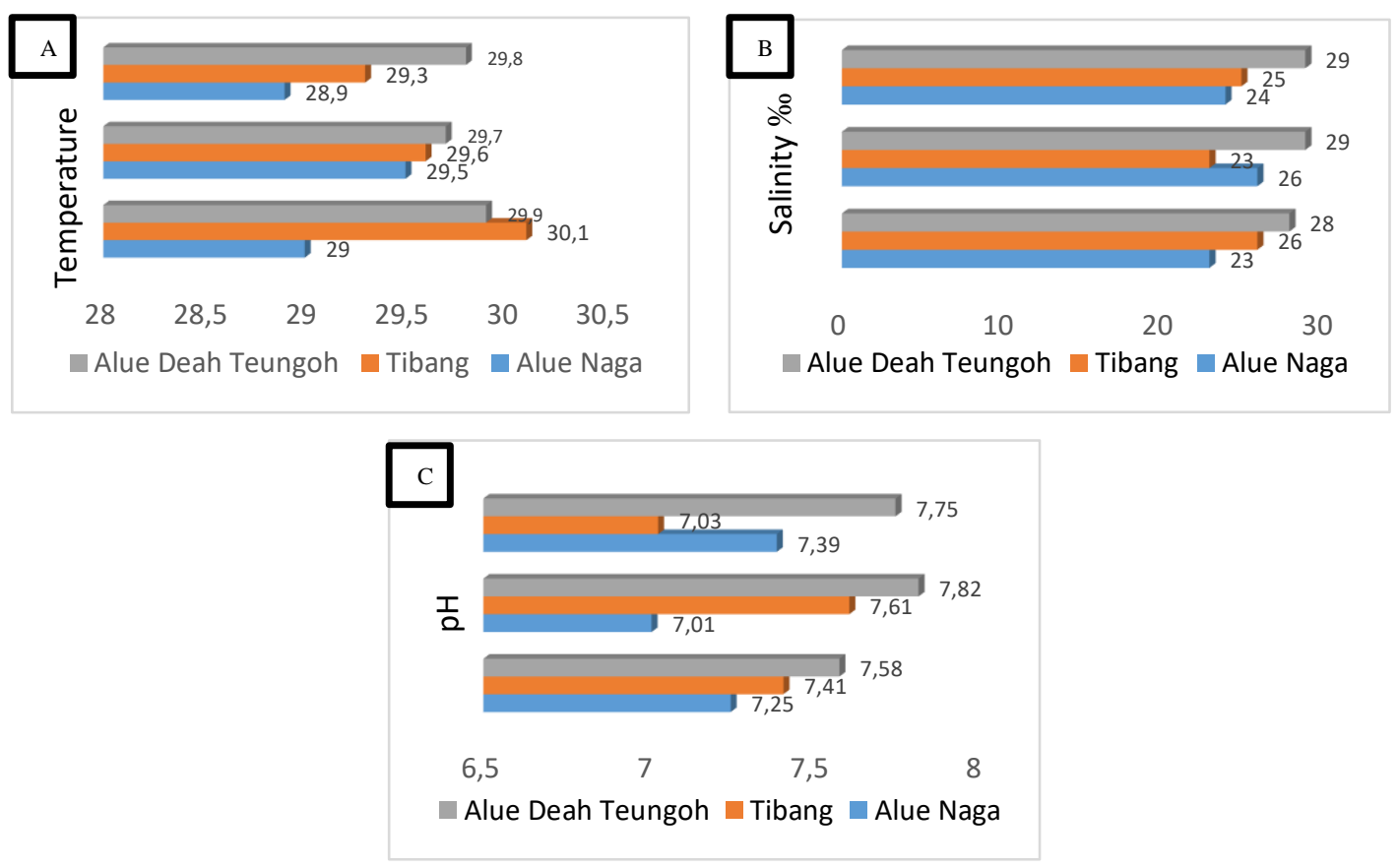

Figure 5. Temperature (A), Salinity (B) and $\mathrm{pH}(\mathrm{C})$

The temperature in the waters is still in the range that corresponds to the life of the oyster. Changes in temperature will affect the suitability of waters as a habitat for aquatic organisms because each aquatic organism has a maximum and minimum range [5]. Temperature plays an important role in the physiological activity of oysters in water, such as filtration and metabolic activities. Water $\mathrm{pH}$ parameters are in the range suitable for oyster growth. Changes in $\mathrm{pH}$ in the water can affect physiology, including reproduction, breeding, and activity of oysters [19]. 
Salinity measured in the water area is in the normal range with salinity between $23-29 \%$ according to the life of the oyster. These results indicate that the water quality in the habitat is still in a good range for the growth of oysters. Oyster life also depends on the type of substrate underwater as a habitat (Table 1).

Table 1. Substrate bottom waters at the observation site

\begin{tabular}{llcc}
\hline Information & Alue Naga & Tibang & $\begin{array}{c}\text { Alue Deah } \\
\text { Teungoh }\end{array}$ \\
\hline Category & $\begin{array}{l}\text { Sand is } \\
\text { clumped }\end{array}$ & $\begin{array}{l}\text { Sand is } \\
\text { clumped }\end{array}$ & Sand \\
\hline
\end{tabular}

The substrate has a role in maintaining sediment stability which includes protection from water flow and processing and nutrient intake. The type and size of the substrate are one of the factors affecting the content of organic matter and benthic distribution [4]. Substrates also affect the installation of aquaculture, water exchange, accumulation of metabolic products and impurities [15]. The basic substrate suitable for oyster culture is a group of coral reefs or sandy corals [8] and [14]. The results of this study produce data that is the sandy substrate in the Alue Deah teungoh and sandy waters in the Alue Naga and Tibang waters. The basic substrate is sandy and sandy loam according to oyster life because it has abundant food availability. [12] The finer the texture of the substrate, the higher the ability to trap organic material which can increase the availability of food for the habitat. In accordance with research [1] that the main factors responsible for the variability of oyster growth are food availability, salinity, and temperature.

\section{Conclusion}

The pattern of oyster growth in the waters of Banda Aceh City occurs negatively allometrically (b <3). The coefficient of determination $\left(\mathrm{R}^{2}\right)$ produced in the culture medium is higher than the natural habitat. The quality of aquatic water and the substrate in the habitat is in the optimal range and in accordance with the provisions of the life of the oysters. This shows that cultivation media is very effective in the production of oysters.

\section{Acknowledgments}

We are thankfull to The Faculty of Teacher Training and Education of Syiah Kuala University.

\section{References}

1. Bhattacharyya S, Panigrahi A, Mitra A, et al.: Effect of physico-chemical variables on the growth and condition index of the rock oyster, Saccostrea cucullata(Born) in the Sundarbans, India. Indian Journal of Fisheries. 2010;57(3):13-17.

2. Carranza A, Defeo O, Beck M: Diversity, conservation status and threats to native oysters (Ostreidae) around the Atlantic and Caribbean coasts of South America. Aquatic Conservation: Marine and Freshwater Ecosystems. 2009;19(3):344-353.
3. Chávez-Villalba J, Arreola-Lizárraga A, Burrola-Sánchez, $\mathrm{S}$, et al.: Growth, condition, and survival of the Pacific oyster Crassostrea gigas cultivated within and outside a subtropical lagoon. Aquaculture. 2010;300(1-4):128-136.

4. Dahuri R, Rais J, Ginting SP, et al.: Pengelolaan sumberdaya wilayah pesisir dan lautan secara terpadu. PT. Pradnya Paramita. Jakarta. 2001:328.

5. Effendi H: Telaah kualitas air, bagi pengelolaan sumber daya dan lingkungan perairan. Kanisius. 2003.

6. Effendie MI: Biologi Perikanan. Yayasan Pustaka Nusatama. Yogyakarta. 1997: 92-105.

7. Ghozali I: Analisis Multivariate dengan program SPSS. Semarang: Badan Penerbit Universitas Diponegoro. 2005.

8. Kangkan AL: Studi penentuan lokasi untuk pengembangan budidaya laut berdasarkan parameter fisika, kimia dan biologi di Teluk Kupang, Nusa Tenggara Timur. Program Pasca Sarjana Universitas Diponegoro. 2006.

9. Kothari CR: Research methodology: Methods and techniques. New Age International. 2004.

10. Mallet AL, Carver CE, Hardy M: The effect of floating bag management strategies on biofouling, oyster growth and biodeposition levels. Aquaculture. 2009; 287(3-4):315323.

11. Muzammil W, Wardiatno Y, Butet NA: Rasio panjanglebar karapas, pola pertumbuhan, faktor kondisi, dan faktor kondisi relatif kepiting pasir (Hippa adactyla) di Pantai Berpasir Cilacap dan Kebumen. Jurnal Ilmu Pertanian Indonesia. 2015; 20(1):78-84.

12. Nybakken JW: Biologi laut. Publisher.PT. Gramedia Pustaka Utama, Jakarta.1992:442.

13. Octavina C: Aspek Pemanfaatan Sumberdaya Tiram Daging Sebagai Upaya Pengelolaan Berbasis Struktur Populasi Di Kuala Gigieng, Aceh Besar. Institut Pertanian Bogor. 2014.

14. Radiarta IN, Saputra A, Johan O: Pemetaan kelayakan lahan untuk pengembangan usaha budidaya laut dengan aplikasi inderaja dan sistem informasi geografi di perairan Lemito, Provinsi Gorontalo. Jurnal Penelitian Perikanan Indonesia. 2005;11(1):1-14.

15. Rejeki S: Pengantar budidaya perairan. Badan Penerbit Universitas Diponegoro. Semarang.2001:76.

16. Sravishta IMSK, Arthana IW, Pratiwi MA: Pola dan Parameter Pertumbuhan Ikan Tangkapan Dominan (Oreochromis niloticus, Osteochilus sp. dan Xiphophorus helleri) di Danau Buyan Bali. Journal of Marine and Aquatic Sciences. 2018; 4(2):204-212.

17. Wilberg MJ, Livings ME, Barkman JS, et al.: Overfishing, disease, habitat loss, and potential extirpation of oysters in upper Chesapeake Bay. Marine Ecology Progress Series. 2011;436:131-144.

18. Winanto T: Memproduksi benih tiram mutiara. Jakarta: Penebar Swadaya. 2004.

19. Yanti H, Muliani M, Khalil M: Pengaruh salinitas yang berbeda terhadap tingkat pertumbuhan dan kelangsungan hidup tiram (Crassostrea sp). Acta Aquatica: Aquatic Sciences Journal. 2017; 4(2):53-58. 